\title{
Histamine Induces Bovine Rumen Epithelial Cell Inflammatory Response via NF-kB Pathway
}

\author{
Xudong Sun ${ }^{\mathrm{a}}$ Xue Yuan ${ }^{\mathrm{b}}$ Liang Chen ${ }^{\mathrm{c}}$ Tingting Wang ${ }^{\mathrm{a}}$ Zhe Wang ${ }^{\mathrm{a}}$ \\ Guoquan Sun ${ }^{b}$ Xiaobing Lia Xinwei Lia Guowen Liu ${ }^{a}$ \\ aKey Laboratory of Zoonosis, Ministry of Education, College of Veterinary Medicine, Jilin University, \\ Changchun, ${ }^{b}$ College of Animal Science and Technology, Inner Mongolia National University, Tongliao, \\ cHeilongjiang Institute of Veterinary Science, Qiqihar, China
}

\section{Key Words}

Subacute ruminal acidosis $\bullet$ Histamine $\bullet$ Inflammatory response $\bullet$ Bovine rumen epithelial cells

\begin{abstract}
Background/Aims: Subacute ruminal acidosis (SARA) is a common disease in highproducing lactating cows. Rumenitis is the initial insult of SARA and is associated with the high concentrations of histamine produced in the rumen of dairy cows during SARA. However, the exact mechanism remains unclear. The objective of the current study is to investigate whether histamine induces inflammation of rumen epithelial cells and the underlying mechanism of this process. Methods: Bovine rumen epithelial cells were cultured and treated with different concentrations of histamine and pyrrolidine dithiocarbamate (PDTC, an NF$\mathrm{KB}$ inhibitor) cultured in different $\mathrm{pH}$ medium ( $\mathrm{pH} 7.2$ or 5.5). qRT-PCR, Western-blotting, ELISA and immunocytofluorescence were used to evaluate whether histamine activated the NF-kB pathway and inflammatory cytokines. Results: The results showed that histamine significantly increased the activity of IKK $\beta$ and the phosphorylation levels of IKB $\alpha$, as well as upregulated the mRNA and protein expression levels of NF-KB p65 in the rumen epithelial cells cultured in neutral $(\mathrm{pH}=7.2)$ and acidic $(\mathrm{pH}=5.5)$ medium. Furthermore, histamine treatment also significantly increased the transcriptional activity of NF- $\mathrm{kB}$ p65. High expression and transcriptional activity of NF- $\mathrm{kB}$ p65 significantly increased the mRNA expressions and concentrations of inflammatory cytokines, tumor necrosis factor alpha (TNF- $\alpha$ ), interleukin 6 (IL-6) and interleukin 1 beta (IL-1ß), thereby inducing the inflammatory response in bovine rumen epithelial cells. However, inhibition of NF-kB p65 by PDTC significantly decreased the expressions and concentrations of the inflammatory cytokines induced by histamine in the rumen epithelial cells cultured in the neutral and acidic medium. Conclusion: The present data indicate that histamine induces the inflammatory response of bovine rumen epithelial cells through the NF-kB pathway.

$X$. Sun and $X$ Yuan contributed equally to this study. 


\section{Cellular Physiology Cell Physiol Biochem 2017;42:1109-1119

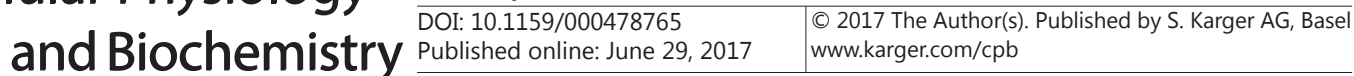 \\ Sun et al.: Histamine Induces Inflammation}

\section{Introduction}

Subacute ruminal acidosis (SARA) is a common and costly disease in intensive dairy herds [1-4]. Based on occurrence data for the prevalence of SARA in dairy cows, in grazing Irish dairy cows the incidence of SARA is 11\% [5], in an Iranian field survey the incidence of SARA is $27 \%$ in early- and mid-lactation cows [6]. Furthermore, the most recent study by Stefańska et al. also found 14\% prevalence from a total of 213 cows [7]. SARA leads to diarrhea, rumen mucosal damage, laminitis, rumenitis, and liver abscesses in dairy cows [8]. The wide prevalence and inherent danger of SARA is indeed a global health problem in highproducing lactating cows that affects rumen fermentation, animal welfare, productivity and farm profitability.

Highly fermentable diets are often fed to high-producing lactating cows to increase milk production, which can reduce the ruminal $\mathrm{pH}$, microbial activity and increase the risk of SARA $[9,10]$. During SARA, the rate of rumen short-chain fatty acid (SCFA) production exceeds SCFA absorption and results in an unhealthy depression of the rumen $\mathrm{pH}$. Ruminal acids are considered the main contributors to the pathophysiology of SARA [9]. Furthermore, with the decrease of the ruminal $\mathrm{pH}$, ruminal bacteria were further lysed and fermented, which produced substantial amounts of lipopolysaccharide and histamine. Studies have shown that a high concentration of ruminal histamine is a potent inducer of acidotic rumenitis in SARA dairy cows [11]. Wang et al. found that the histamine concentration in the ruminal fluid increased from 46.4 to $161.2 \mu \mathrm{M}$ during experimental engorgement, and plasma histamine concentration increased from a norm of $2.03 \mu \mathrm{M}$ to $7.92 \mu \mathrm{M}$ [12]. It has been suggested that high concentrations of ruminal histamine significantly induce epithelial damage [11], which reduces the energy available to support production.

The pathogenesis of rumenitis in SARA cows is multifactorial and the imbalance between pro- and anti-inflammatory mediators may play an important role in the development and progression of this disease. Rumenitis is the initial insult of SARA and is the inflammatory response of rumen epithelial cells. A recent study has been indicated that histamine functions, as a signaling molecule, activating some signal pathways involved in inflammation of endothelial cells [13]. The nuclear factor- $\kappa B(N F-\kappa B)$ plays a key role in the regulation of the inflammatory response by controlling the transcription of pro-inflammatory genes

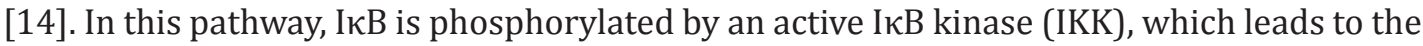

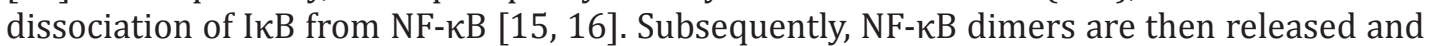
translocated to the nucleus to activate pro-inflammatory gene transcription by synthesizing cytokines, such as tumor necrosis factor alpha (TNF- $\alpha$ ), interleukin 6 (IL-6) and interleukin 1 beta (IL-1ß) [17]. Moreover, clinical investigations have suggested that dairy cows with highconcentrate feeding are characterized by elevated expression of inflammation-related genes in the ruminal epithelium in vivo [18] and accumulation of a high concentration of histamine in the ruminal fluid [12]. Thus, we speculated that the NF- $\kappa B$ pathway might be part of the histamine regulation mechanism in the expression of inflammatory genes in rumen epithelial cells. The objective of this study is to investigate whether histamine induces inflammation of rumen epithelial cells and the underlying mechanism. The results of this study provide novel insights into the pathogenesis of rumenitis in SARA.

\section{Materials and Methods}

The study protocol was approved by the Ethics Committee on the Use and Care of Animals, Jilin University (Changchun, China). The animals' studies were performed in accordance with the Guiding Principles of Animals adopted by the Chinese Association for Laboratory Animal Sciences.

Isolation of cattle primary rumen epithelium cell

The rumen was obtained through surgical excision from 6 neonatal (24-hour-old) female Holstein cows anesthetized with thiamylal sodium under sterile conditions. Following a sterile water wash, the 


\section{Cellular Physiology Cell Physiol Biochem 2017;42:1109-1119 \begin{tabular}{l|l} 
DOI: 10.1159/000478765 & and Biochemistry \\
Published online: June 29, 2017 & $\begin{array}{l}\text { O 2017 The Author(s). Published by S. Karger AG, Basel } \\
\text { www.karger.com/cpb }\end{array}$
\end{tabular} \\ Sun et al.: Histamine Induces Inflammation}

rumen was transported immediately to plates in cold D-Hank's buffer. The tissues were cut into small pieces ( 3 to $4 \mathrm{~cm}^{2}$ ) and sterilized with penicillin $(2500 \mathrm{U} / \mathrm{mL})$ and streptomycin $(2500 \mathrm{mg} / \mathrm{mL})$ solution for 30 min. Then, the tissues were washed with amphotericin B (1000 U/mL) and gentamicin $(12 \mu \mathrm{g} / \mathrm{mL})$ solution for $30 \mathrm{~min}$. Cells were isolated from the mucosae using a digestion solution containing $0.25 \%$ trypsin and $0.02 \%$ EDTA-Na ${ }_{2}$ for $15-20$ min. The solution was filtered sequentially with 100 mesh $(150 \mu \mathrm{m})$ cell sieves. Cells were isolated using four to six cycles of digestion with fresh trypsin solution. An equal volume of Dulbecco's Modified Eagle's medium (DMEM) containing 15\% fetal bovine serum was added to terminate tryptic digestion. Then, the cell suspensions were washed twice with D-Hank's buffer and filtered twice with 300 mesh $(37.5 \mu \mathrm{m})$ cell sieves. The suspensions were then centrifuged for $10 \mathrm{~min}$ at $1000 \mathrm{rpm}$. The cells were resuspended and the densities were adjusted to $1 \times 10^{6}$ cells $/ \mathrm{mL}$. The cell suspensions were seeded sequentially into 24-well tissue culture plates on glass coverslips (1 mL/well) and 6-well tissue culture plates ( $2 \mathrm{~mL} /$ well) and incubated at $37^{\circ} \mathrm{C}$ and $5 \% \mathrm{CO}_{2}$ in a humidified incubator. After $24 \mathrm{~h}$, the medium was replaced with DMEM medium containing 15\% fetal calf serum, $200 \mathrm{U} / \mathrm{ml}$ penicillin, $200 \mathrm{mg} /$ $\mathrm{mL}$ streptomycin, $6 \mu \mathrm{g} / \mathrm{mL}$ gentamicin, and $6 \mu \mathrm{g} / \mathrm{mL}$ amphotericin B. The medium was replaced every $24 \mathrm{~h}$.

\section{Cell treatments}

The histamine used in this study was based on the concentration of rumen fluid histamine in healthy and SARA dairy cows. For the time course experiments, the rumen epithelial cells were treated with 12.5 $\mu \mathrm{M}$ histamine (H-7125, Sigma-Aldrich, St. Louis, MO, USA) for 0, 1, 3, 6, 9, 12 or $24 \mathrm{~h}$. For the dose response experiments, cells were treated with histamine and pyrrolidine dithiocarbamate (PDTC). PDTC is an NF- $\mathrm{B}$ inhibitor that inhibits the activation and translocation of NF- $\kappa B$ from the cytoplasm into the nucleus [19]. The rumen epithelial cells were treated with $0 \mu \mathrm{M}$ histamine, $0.5 \mu \mathrm{M}$ histamine, $2.5 \mu \mathrm{M}$ histamine, $12.5 \mu \mathrm{M}$ histamine, $62.5 \mu \mathrm{M}$ histamine, $10 \mu \mathrm{M}$ PDTC, or $12.5 \mu \mathrm{M}$ histamine $+10 \mu \mathrm{M}$ PDTC in pH 7.2 medium for $6 \mathrm{~h}$. SARA was defined as a depression of ruminal pH below 5.6 exceeding $3 \mathrm{~h}$ per day [20, 21]. To determine whether low $\mathrm{pH}$ effects the rumen epithelial cells treated with histamine, the rumen epithelial cells were pretreated with pH 5.5 medium for $3 \mathrm{~h}$ prior to treatment as described above. The $\mathrm{pH}$ of the medium was adjusted to 5.5 with $1 \mathrm{mM} \mathrm{HCl}$ solution.

\section{IKK $\beta$ activity determination}

The rumen epithelial cells were treated as described above, the cells washed twice in ice-cold GENMED clean buffer (Reagent A, GenMed Scientifics Inc., USA) for $5 \mathrm{~min}$ at $300 \times g$ at $4^{\circ} \mathrm{C}$. Subsequently, the cells were treated with lysis buffer (Reagent B) and incubated for $30 \mathrm{~min}$ in an ice bath. The lysate was centrifuged for $5 \mathrm{~min}$ at $16,000 \times g$ at $4^{\circ} \mathrm{C}$, and the IKK $\beta$ activity in the supernatant was measured using a spectrophotometer and a biochemical kit (Reagent A, GenMed Scientifics Inc., USA) according to the manufacturer's instructions.

\section{Determinationof TNF- $\alpha, I L-6$, and IL-1 $\beta$ concentration}

After the rumen epithelial cells were treated as described above, the cell-free supernatants in each group were collected and centrifuged at $3000 \mathrm{rpm}$ for $20 \mathrm{~min}$. The supernatants were extracted and used to determine the concentrations of the inflammatory cytokines TNF- $\alpha$, IL- 6 , and IL- $1 \beta$ with an enzyme-linked immunosorbent assay kit (TNF- $\alpha$ : ml024586; IL-6: ml023908; IL-1ß: ml023899; Shanghai Enzyme-linked Biotechnology Co., Ltd., Shanghai, China), following the manufacturer's instructions.

\section{RNA extraction and real-time quantitative PCR ( $q R T-P C R)$}

Total RNA was extracted using Trizol (Invitrogen, Grand Island, NY, USA) according to the manufacturer's instructions. The concentration of RNA was detected using an RNA/DNA calculator (Cambridge, UK). The RNA was reverse-transcribed to cDNA with the reverse transcription kit (TaKaRa Biotechnology Co., Ltd., Tokyo, Japan) according to the supplier's protocol. The relative expression of the target genes was determined by the $2^{-\Delta \Delta \mathrm{CT}}$ method [22]. $\beta$-actin mRNA was used as an internal control. The relative mRNA concentrations were detected by qRT-PCR using a 7500 Real-Time PCR System (Applied Biosystems, USA) and a SYBR green plus reagent kit (Roche, Norwalk, CT, USA). The conditions were as follows: $95^{\circ} \mathrm{C}$ for $3 \mathrm{~min}$, followed by 40 cycles of $95^{\circ} \mathrm{C}$ for $15 \mathrm{sec}$ and $60^{\circ} \mathrm{C}$ for $1 \mathrm{~min}$. The primers of the genes are shown in Table 1. 


\section{Cellular Physiology Cell Physiol Biochem 2017;42:1109-1119 \begin{tabular}{ll|l} 
DOI: 10.1159/000478765 & O 2017 The Author(s). Published by S. Karger AG, Basel \\
www.karger.com/cpb
\end{tabular}}

Sun et al.: Histamine Induces Inflammation

Table 1. The primer sequences of the genes

\begin{tabular}{llc}
\hline Gene & Primer sequences (5'-3') & Length (bp) \\
\hline NF-kB p65 & F AGGACCAACCAGACCG & 240 \\
& R TGTCACCAGGCGAGTTAT & \\
IL6 & F AACGAGTGGGTAAAGAACGC & 144 \\
& R CTGACCAGAGGAGGGAATGC & \\
IL1 $\beta$ & F CTGAACCCATCAACGAAA & 190 \\
& R ATGACCGACACCACCTGC & \\
TNF- $\alpha$ & F CTGCCGGACTACCTGGACTAT & 234 \\
& R CCTCACTTCCCTACATCCCTAA & \\
$\beta$-actin & F GCCCTGAGGCTCTCTTCCA & 101 \\
& R GCGGATGTCGACGTCACA & \\
\hline
\end{tabular}

Protein extraction and Western blotting

Total proteins were extracted using a protein extraction kit (Sangon Biotech Co., Ltd, Shanghai, China) according to the manufacturer's instructions. Protein content was quantified using BCA protein assay reagent (Beyotime Institute of Biotechnology, Jiangsu, China). The protein (10 to $40 \mu \mathrm{g}$ per lane, depending on protein of interest) was separated using sodium dodecyl sulfate-polyacrylamide gels electrophoresis, which was electro-transferred onto PVDF membranes. Then, the PVDF membranes were incubated with

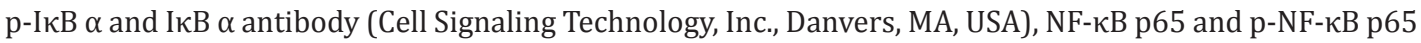
(Abcam, Cambridge, UK) and $\beta$-actin (Santa Cruz, USA). Subsequently the PVDF membranes were incubated with an appropriate secondary antibody (Boster, Wuhan, China). Finally, protein bands were observed using the enhanced chemiluminescent (ECL) reagent (ECL, Pierce Biotechnology Inc., Chicago, IL, USA). Protein grey intensity was quantified by the Gel-Pro Analyzer program normalized to $\beta$-actin levels. Each Western blot was performed a total of three times.

\section{Immunocytofluorescence}

The cells were grown on glass coverslips to $90 \%$ confluency and subjected to histamine and/or PDTC treatments as described above. The coverslips were then washed thrice with PBS, fixed with $4 \% \mathrm{w} / \mathrm{v}$ paraformaldehyde in PBS for 20 min at room temperature, subjected to antigen retrieval with EDTA-Na $\left(95^{\circ} \mathrm{C}, 5 \mathrm{~min}\right.$ ) and permeabilized with $0.1 \%$ Triton X-100 (Sigma-Aldrich, St. Louis, MO). They were then washed thrice with PBS and blocked with a goat-serum-containing blocking buffer. After washing thrice with PBS, the cells were exposed to the primary antibody NF- $\kappa B$ p65 (Abcam, Cambridge, UK) in PBS at $4^{\circ} \mathrm{C}$ overnight, incubated with goat anti-rabbit IgG conjugated with Cy3 (Beyotime Institute of Biotechnology) in PBS at room temperature for $30 \mathrm{~min}$ and counterstained with Hoechst 33258 (Beyotime Institute of Biotechnology). The coverslips were observed and photographed using laser-scanning confocal microscopy (Fluoview FV1200, Olympus, Japan).

\section{Statistical analysis}

Statistical analyses were done using SPSS 13.0 for Windows (SPSS Inc., Chicago, IL, USA). An ANOVA was performed to evaluate the differences among the groups followed by LSD post. The results are presented as the mean \pm standard deviation (SD, bar on the top of each column). $P$ values of less than 0.05 were considered significant, and $P$ values of less than 0.01 were considered markedly significant.

\section{Results}

Effects of histamine on IKB $\alpha$ phosphorylation in rumen epithelial cells at different time points

To determine the effects of histamine treatment time on the phosphorylation levels of IкB $\alpha$, rumen epithelial cells were treated with $12.5 \mu \mathrm{M}$ histamine for different time points. As shown in Fig. 1, the phosphorylation levels of IкB $\alpha$ (p-ІкB $\alpha / \mathrm{I} \kappa B \alpha$ ) were significantly higher in the histamine-treated group than in the control group at 3, 6 and $9 \mathrm{~h}$, and were highest at $6 \mathrm{~h}$ in the histamine-treated group (Fig. $1 \mathrm{~A}$ and B; $P<0.05$ and $P<0.01$ ). Thus, 6 $\mathrm{h}$ was selected as the optimum time point for the follow-up experiment. 
Fig. 1. Effect of histamine on $I \kappa B$ phosphorylation in rumen epithelial cells at different time points. Rumen epithelial cells were treated with $12.5 \mu \mathrm{M}$ of histamine for $0,1,3,6,9,12$ or $24 \mathrm{~h}$, respectively. (A) Western blotting results of $\mathrm{p}-\mathrm{I} \kappa \mathrm{B} \alpha$ and I $\mathrm{I} \mathrm{B} \alpha$. (B) The phosphorylation levels of I $\mathrm{B} \alpha$. The data presented are the mean \pm SD. *, statistical significance $(P<0.05) .{ }^{* *}$, statistical significance $(P<0.01)$. The symbols $*$ and ${ }^{* *}$ indicate significant differences with the control group $(0 \mathrm{~h})$.
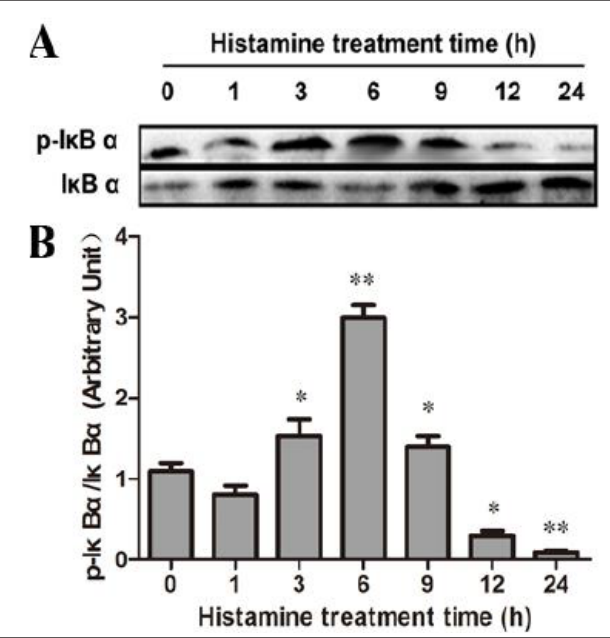

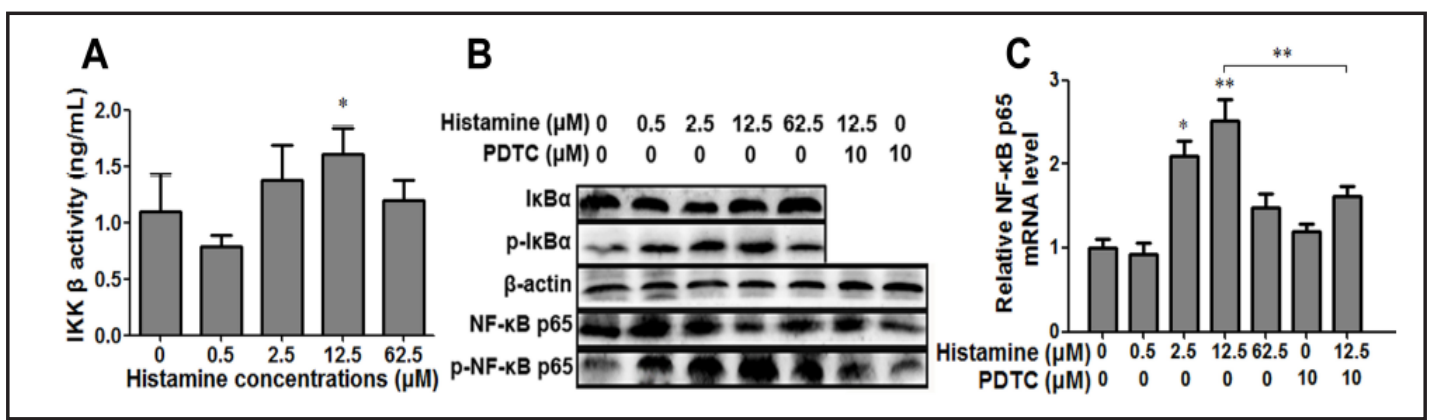

Fig. 2. Histamine activates the NF- $\kappa B$ pathway in rumen epithelial cells cultured in neutral medium. The rumen epithelial cells were treated with $0 \mu \mathrm{M}$ histamine, $0.5 \mu \mathrm{M}$ histamine, $2.5 \mu \mathrm{M}$ histamine, $12.5 \mu \mathrm{M}$ histamine, $62.5 \mu \mathrm{M}$ histamine, $10 \mu \mathrm{M}$ PDTC or $12.5 \mu \mathrm{M}$ histamine $+10 \mu \mathrm{M}$ PDTC in pH 7.2 medium for $6 \mathrm{~h}$. (A) The activity of IKK $\beta$ detected by an ELISA kit; (B) Western blotting analysis of $\mathrm{p}$-I $\kappa \mathrm{B} \alpha, \mathrm{I} \kappa \mathrm{B} \alpha, \mathrm{p}-\mathrm{NF}-\kappa \mathrm{B}$ p65 and NF- $\kappa B$ p65; (C) mRNA expression level of NF- $\kappa B$ p65. The data presented are the mean \pm SD. *, statistical significance $(P<0.05)$. ${ }^{* *}$, statistical significance $(P<0.01)$. The symbols $*$ and ${ }^{* *}$ indicate significant differences with the control group (no histamine and no PDTC), and the two groups that are marked with horizontal lines are significantly different.

Histamine activates the NF- $\mathrm{B}$ pathway in rumen epithelial cells cultured with neutral medium

To investigate whether histamine activates the NF- $\mathrm{B}$ inflammatory pathway in the rumen epithelial cells, cells were treated with different concentrations of histamine and/ or PDTC in pH 7.2 medium for $6 \mathrm{~h}$. The activity of IKK $\beta$ was significantly higher in the 12.5 $\mu \mathrm{M}$ histamine treatment group than in the control group (Fig. $2 \mathrm{~A} ; P<0.05$ ). Similarly, the phosphorylation levels of IкB $\alpha$ were also increased in the histamine treatment groups and were significantly higher in the $0.5,2.5$ and $12.5 \mu \mathrm{M}$ histamine treatment groups than in the control group (Fig. 2B). The phosphorylation levels of NF- $\kappa B$ p65 (p-NF- $\kappa B$ p65/NF- $\kappa B$ p65) and mRNA expression of NF- $\kappa B$ p65 were significantly higher in the 2.5 and $12.5 \mu \mathrm{M}$ histamine treatment groups than in the control group, but they significantly lower in the histamine + PDTC treatment group than in the $12.5 \mu \mathrm{M}$ histamine treatment group (Fig. 2B and C; $P<0.05$ and $P<0.01$ ). These results indicate that histamine over activates the NF- $\mathrm{BB}$ inflammatory pathway in bovine rumen epithelial cells.

To evaluate the transcriptional activity of NF- $\kappa B$ p65 in bovine rumen epithelial cells after histamine treatment, immunocytofluorescence was performed. The results showed that histamine increased NF- $\mathrm{kB}$ p65 translocation to the nucleus and the fluorescence intensity in the nucleus was significantly higher in the $12.5 \mu \mathrm{M}$ histamine treatment group 


\section{Cellular Physiology Cell Physiol Biochem 2017;42:1109-1119 \begin{tabular}{ll|l} 
DOI: 10.1159/000478765 & a 2017 The Author(s). Published by S. Karger AG, Basel \\
www.karger.com/cpb
\end{tabular}

Fig. 3. Immunofluorescence staining of $\mathrm{NF}-\kappa \mathrm{B}$ p65 in bovine rumen epithelial cells. Cells were treated as described in Fig. 2. Images were merged with Hoechst 33258 staining images.
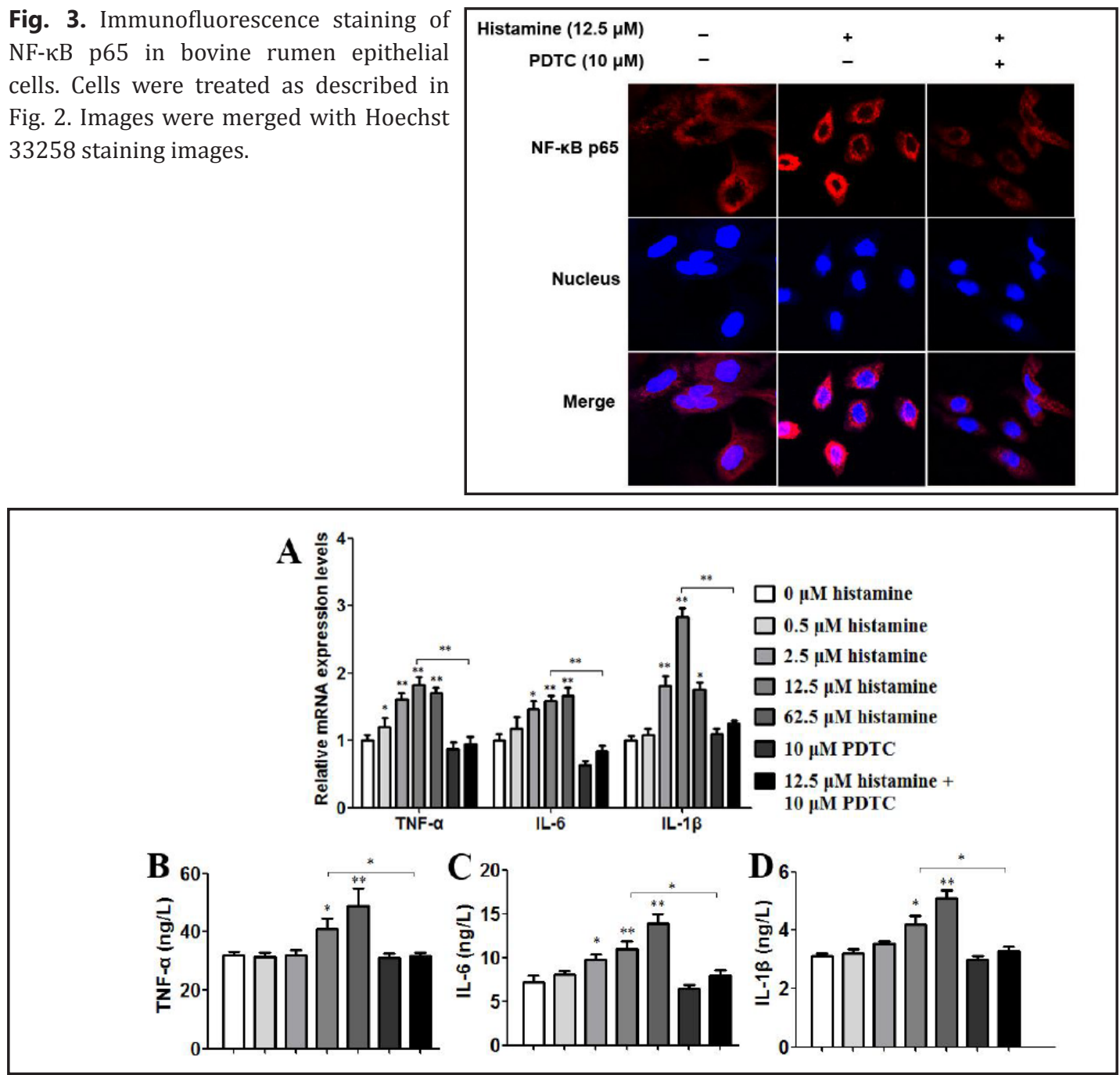

Fig. 4. Effects of histamine on the mRNA expressions and concentrations of pro-inflammatory cytokines in rumen epithelial cells cultured in neutral medium. Cells were treated as described in Fig. 2. (A) the mRNA expressions of TNF- $\alpha$, IL-6, and IL-1 $\beta$; (B, C and D) the concentrations of TNF- $\alpha$, IL- 6 , and IL-1 $\beta$, respectively. The data presented are the mean \pm SD. ${ }^{*}$, statistical significance $(P<0.05){ }^{* *}$, statistical significance $(P<$ 0.01 ). The symbols $*$ and $* *$ indicate the significant differences with the control group (no histamine and no PDTC), and the two groups that are marked with horizontal line are significantly different.

than in the control group. However, it was significantly decreased in the histamine + PDTC treatment group compared with $12.5 \mu \mathrm{M}$ histamine treatment group (Fig. 3). Overall, these results indicate that histamine can increase NF- $\mathrm{KB}$ p65 transcriptional activity in bovine rumen epithelial cells.

Effects of histamine on the MRNA expressions and concentrations of pro-inflammatory cytokines in rumen epithelial cells cultured with neutral medium

Over-activation of NF- $\kappa \mathrm{B}$ pathways could promote the expression of inflammatory cytokines [17]. Thus, we next studied the consequences of over-activation NF- $\kappa B$ pathways on the inflammatory cytokines in cultured bovine rumen epithelial cells. The mRNA expressions and concentrations of TNF- $\alpha$, IL-6, and IL-1 $\beta$ were significantly higher in the histamine treatment groups than in the control group (Fig. 4A, B, C and D; $P<0.05$ and $P$ $<0.01$ ), while administration of PDTC significantly decreased the mRNA expressions and concentrations of TNF- $\alpha$, IL- 6 , and IL-1 $\beta$ compared with the $12.5 \mu \mathrm{M}$ histamine treatment 


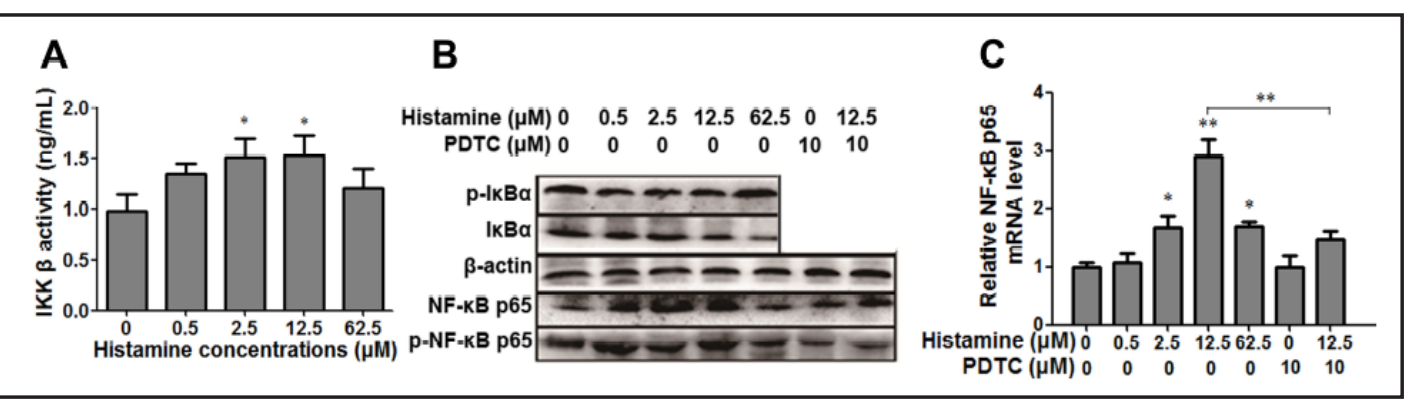

Fig. 5. Histamine activates the NF- $\kappa B$ pathway in rumen epithelial cells cultured in acidic medium. The rumen epithelial cells were pretreated with pH 5.5 medium for $3 \mathrm{~h}$ prior to stimulation with $0 \mu \mathrm{M}$ histamine, $0.5 \mu \mathrm{M}$ histamine, $2.5 \mu \mathrm{M}$ histamine, $12.5 \mu \mathrm{M}$ histamine, $62.5 \mu \mathrm{M}$ histamine, $10 \mu \mathrm{M}$ PDTC or $12.5 \mu \mathrm{M}$ histamine $+10 \mu \mathrm{M}$ PDTC for $6 \mathrm{~h}$. (A) The activity of IKK $\beta$ detected by ELISA kit; (B) Western blotting analysis of

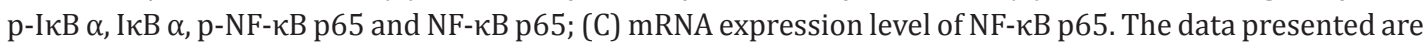
the mean \pm SD. *, statistical significance $(P<0.05)$. ${ }^{* *}$, statistical significance $(P<0.01)$. The symbols $*$ and ${ }^{* *}$ indicate significant differences with the control group (no histamine and no PDTC), and the two groups that are marked with horizontal line are significantly different.

group. These results indicate that histamine induces the expression and synthesis of inflammatory cytokines in bovine rumen epithelial cells through over activation of the NF$\kappa \mathrm{B}$ inflammatory pathway.

Histamine activates the NF- $\kappa B$ pathway in rumen epithelial cells pretreated with acidic medium

The aforementioned results suggest that histamine induces bovine rumen epithelial cell inflammation through activation of the NF- $\mathrm{KB}$ pathway in neutral medium. SARA is defined as a disorder associated with low rumen $\mathrm{pH}$, which falls below 5.6 at least $3 \mathrm{~h} /$ day $[20,21]$. To further clarify whether low $\mathrm{pH}$ affects histamine on the activation of NF- $\kappa \mathrm{B}$ pathway, the rumen epithelial cells were pretreated with $\mathrm{pH} 5.5$ medium for $3 \mathrm{~h}$ prior to stimulation with different concentrations of histamine and/or PDTC for $6 \mathrm{~h}$. The activity of IKK $\beta$ (Fig. 5A; $P<$ 0.05), phosphorylation levels of I $\mathrm{B} \alpha$ (Fig. 5B), phosphorylation levels and mRNA expression of NF-kB p65 (Fig. 5B and C; $P<0.05$, and $P<0.01$ ) were all significantly higher in the histamine treatment groups than in the control group under acidic conditions. Administration of PDTC significantly decreased the phosphorylation levels and mRNA expression of NF- $\kappa B$ p65 compared with the $12.5 \mu \mathrm{M}$ histamine treatment group (Fig. 5B and C). Furthermore, histamine increased NF- $\kappa$ B p65 translocation to the nucleus, and the fluorescence intensity in the nucleus was significantly higher in the $12.5 \mu \mathrm{M}$ histamine treatment group than in the control group under acidic conditions. However, it was significantly decreased in PDTC treatment group under acidic conditions (Fig. 6). These results indicate that pretreatment of acidic medium with histamine also induces the over activation of the NF- $\kappa$ B inflammatory pathway in bovine rumen epithelial cells.

Effects of histamine on the mRNA expressions and concentrations of pro-inflammatory cytokines in rumen epithelial cells pretreated with acidic medium

As shown in Fig. 7, the mRNA expressions and concentrations of TNF- $\alpha$, IL-6, and IL$1 \beta$ were significantly higher in the histamine treatment groups than in the control group under acidic conditions (Fig. 7A, B, C and D; $P<0.05$, and $P<0.01$ ), while administration of PDTC significantly decreased the mRNA expressions and concentrations of TNF- $\alpha$, IL-6, and IL-1 $\beta$ compared with the $12.5 \mu \mathrm{M}$ histamine treatment group under acidic conditions. Taken together, these results indicate that pretreatment of acidic medium with histamine also increases inflammatory cytokines expression and synthesis via over activation of the NF- $\kappa B$ inflammatory pathway, which further mediates the inflammation response in bovine rumen epithelial cells.

\section{KARGER}




\section{Cellular Physiology Cell Physiol Biochem 2017;42:1109-1119 \begin{tabular}{l|l} 
DOI: 10.1159/000478765 & O 2017 The Author(s). Published by S. Karger AG, Basel \\
www.karger.com/cpb
\end{tabular} Sun et al.: Histamine Induces Inflammation}

Fig. 6. Immunofluorescence staining of NF-кB p65 bovine rumen epithelial cells. Cells were treated as described in Fig. 5. Images were merged with Hoechst 33258 staining images.
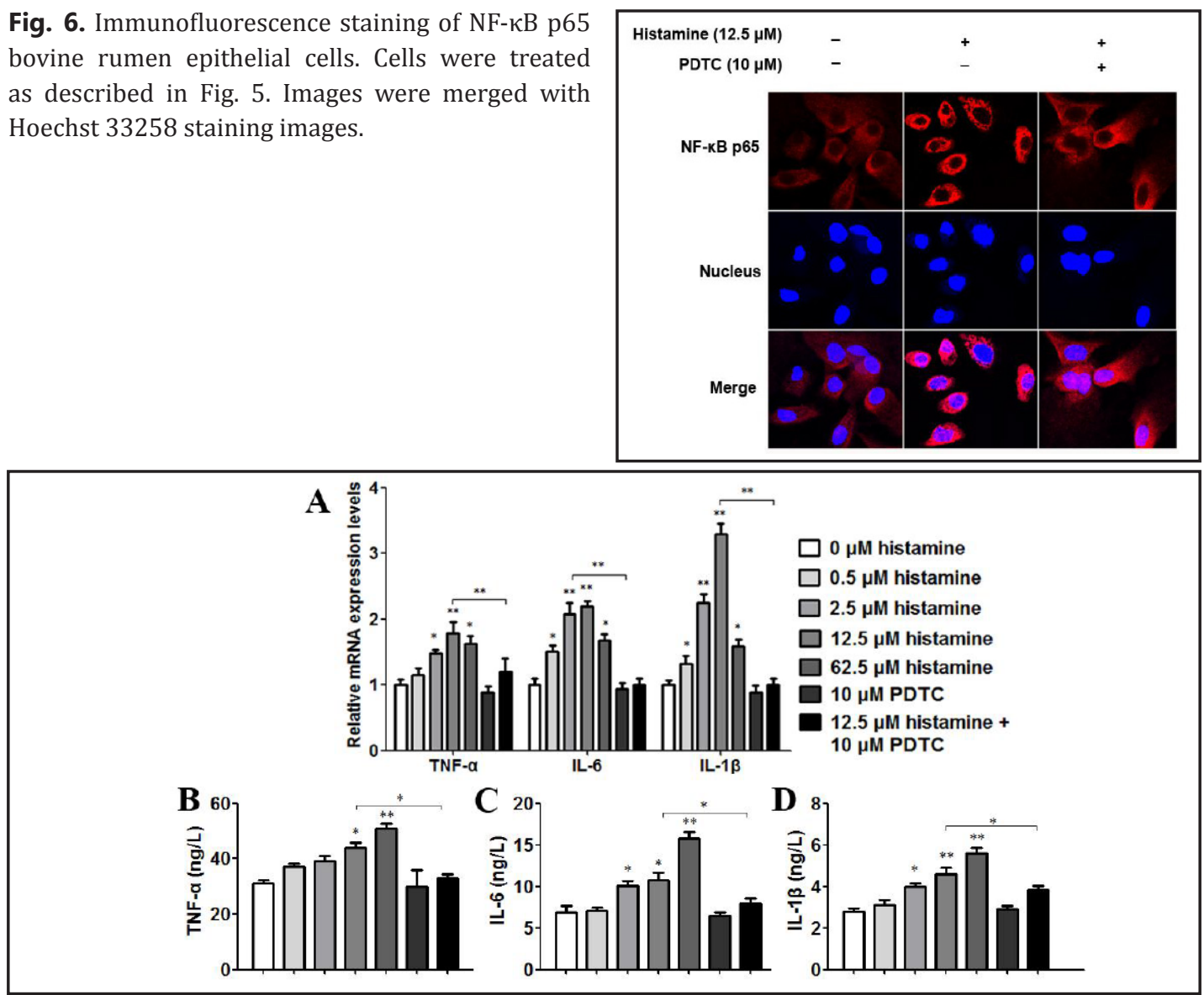

Fig. 7. Effects of histamine on the mRNA expressions and concentrations of pro-inflammatory cytokines in rumen epithelial cells cultured in acidic medium. Cells were treated as described in Fig. 5. (A) the mRNA expressions of TNF- $\alpha$, IL- 6 , and IL-1 $\beta$; (B, C and D) the concentrations of TNF- $\alpha$, IL- 6 , and IL-1 $\beta$. The data presented are the mean \pm SD. ${ }^{*}$, statistical significance $(P<0.05) .{ }^{* *}$, statistical significance $(P<0.01)$. The symbols * and ** indicate significant differences with the control group (no histamine and no PDTC), and the two groups that are marked with horizontal line are significantly different.

\section{Discussion}

SARA is one of the most important metabolic disorders in high-yielding dairy cows [4]. The nutrient density and energy of the cow diet has to be increased by feeding them high concentrates, including rapidly fermentable carbohydrates. However, excessively fermentable diets increase the risk of SARA, which increase the concentration of histamine in rumen. Suber et al. has found that ruminal levels of histamine can rise as high as 3.0 to $70.0 \mu \mathrm{g} / \mathrm{mL}$ during SARA [23]. Histamine is an inflammatory inducer and may induce the development of rumenitis $[11,12]$. In vivo and in vitro studies further demonstrated that histamine can act as signaling molecules involved in regulating the expression of inflammatory cytokines $[13,24]$. Thus, high concentrations of histamine in the rumen are partially responsible for the response to inflammation response of the rumen during SARA [11]. However, the signaling pathway for the regulation of histamine on the expression of inflammatory cytokines remains unclear.

The NF- $\mathrm{KB}$ pathway plays a crucial role in the inflammatory responses that mediate the histamine challenge in rat microglia [25]. Aberrant constitutive NF- $\kappa B$ activation is associated with inflammatory diseases [26]. Canonical NF- $\kappa B$ activation relies on the degradation of IKB which is phosphorylated by an active IKK [16]. In this study, histamine treatment 
significantly increased the activity of IKK $\beta$ in rumen epithelial cells cultured in neutral medium, which promoted the phosphorylation of ІкB [27]. As expected, the phosphorylation levels of IкB $\alpha$ were also significantly increased in rumen epithelial cells treated with histamine. Subsequently, phosphorylation and proteasome-mediated degradation of IкB proteins would activate NF- $\mathrm{KB}$ and facilitate its transportation to nuclear [28]. This trend was observed, histamine significantly increased the protein and mRNA expression and transcriptional activity of NF- $\kappa \mathrm{B}$. Interestingly, $12.5 \mu \mathrm{M}$ histamine significantly activated the NF- $\mathrm{KB}$ inflammatory pathway, whereas $62.5 \mu \mathrm{M}$ histamine had no significant effect on the activation of this pathway. One possible explanation for this effect is that the $62.5 \mu \mathrm{M}$ histamine dose is too high to the adaptation of bovine rumen epithelial cells response to the stimuli. In addition, administration of PDTC reversed the activation effects of histamine on the expression and transcriptional activity of NF- $\mathrm{KB}$ in bovine rumen epithelial cells, indicating that PDTC can alleviate the pro-inflammatory effects of histamine on the signal cascade level. Elevated NF- $\mathrm{KB}$ activity has been recognized as a hallmark of inflammation [29]. Dong et al. reported that the activity of NF- $\mathrm{\kappa B}$ was significantly increased in the microglia of histaminetreated rats [25]. Taken together, previous studies and our results indicate that histamine over activates the NF- $\mathrm{BB}$ inflammatory pathway in bovine rumen epithelial cells. Thus, the elevation of the NF- $\mathrm{KB}$ inflammatory pathway may be one of the molecular mechanisms of rumenitis in SARA cows caused by high fermentable diets.

Over activation of the NF- $\kappa B$ inflammatory pathway could significantly increase the expression of inflammatory cytokines $[16,30]$. TNF- $\alpha$, IL- 6 , and IL-1 $\beta$ are the proinflammatory cytokines, which are the main indexes that reflect the inflammation response [17]. Li et al. found that activation of the NF- $\kappa B$ pathway significantly increased the mRNA expression of TNF- $\alpha$, IL-6, and IL-1 $\beta$ in bovine hepatocytes [31]. In this study, histamine significantly increased the mRNA expressions and concentrations of TNF- $\alpha$, IL- 6 , and IL$1 \beta$ (Fig. 3). These inflammatory cytokines further mediated the inflammation response of the bovine rumen epithelial cells, thereby inducing rumenitis in dairy cows with SARA [18]. Interestingly, inconsistent with the effects of histamine on the NF- $\kappa B$ pathway, the mRNA expressions and concentrations of TNF- $\alpha$, IL- 6 , and IL- $1 \beta$ were all significantly increased in $62.5 \mu \mathrm{M}$ histamine treatment group, which might be explained as that high concentrations of histamine might affect other inflammatory signaling pathways which are involved in the regulation of the TNF- $\alpha$, IL- 6 , and IL- $1 \beta$ expressions. These results emphasized the demand for further investigation into the mechanism of high dose of histamine on the expression of inflammatory cytokines. Moreover, administration of PDTC attenuated the effects of histamine on the mRNA expressions and concentrations of TNF- $\alpha$, IL- 6 , and IL-1 $\beta$, which indicated that histamine induced the inflammation response via activation of the NF- $\kappa$ B pathway. Dong et al. have reported that histamine increases the release of the inflammatory mediators TNF- $\alpha$ and IL- 6 via activation of the NF- $\mathrm{BB}$ inflammatory pathway in rat microglia [25]. Furthermore, dairy cows fed high-concentrate feed are characterized by elevated expression of the inflammation-related genes IL-1 $\beta$, IL-2, IL-22 in the ruminal epithelium in vivo [18]. These studies further demonstrated that over activation of inflammatory pathways and inflammatory cytokines mediated the development of rumenitis in SARA cows. Collectively, the above results indicate that histamine over activates the NF- $\kappa$ B inflammatory pathway and increases the expression of inflammatory cytokines in rumen epithelial cells, which may be partially responsible for the rumenitis in SARA cows caused by high fermentable diets.

SARA was defined as a depression of ruminal pH below 5.6 exceeding $3 \mathrm{~h}$ per day [20, $21]$, which significantly increased the concentration of histamine in the rumen [12, 23]. In this study, we further evaluated whether low $\mathrm{pH}$ affected histamine in the activation of the NF- $\mathrm{BB}$ inflammatory pathway and the expressions of inflammatory cytokines in rumen epithelial cells treated with histamine. We found that pretreatment of acidic medium with histamine also induced high expression of TNF- $\alpha$, IL- 6 , and IL- $1 \beta$ through over activation of the NF- $\kappa B$ pathway, which further mediated the inflammation response in bovine rumen epithelial cells. Taken together, our findings suggest that histamine induces the inflammatory response of

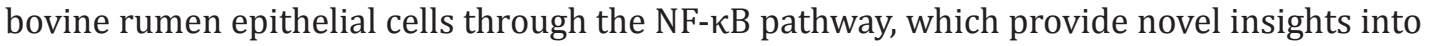

\section{KARGER}


the molecular mechanisms of rumenitis in SARA cows. Furthermore, there are substantial amounts of inflammatory inducers, including volatile fatty acids and lipopolysaccharide, also produced in the rumen of SARA cows, which induces rumen inflammation that may further mediate the development of SARA $[18,32]$. Therefore, it will be interesting to explore the specific role of these inflammatory inducers in the development of SARA in the future.

In summary, our results suggest that histamine can induce the activation of the NF- $\mathrm{BB}$ inflammatory pathway and upregulate the expressions of the inflammatory cytokines TNF- $\alpha$, IL-6, and IL-1 $\beta$, thereby inducing the inflammatory response in bovine rumen epithelial cells.

\section{Acknowledgments}

This work was supported by the National Natural Science Foundation of China (Beijing, China; grant nos. 31360630, 31460681, 31402265 and 31472247) and the National key research and development program (Beijing, China; grant no. 2016YFD0501206).

\section{Disclosure Statement}

None to declare.

\section{References}

1 Plaizier JC, Krause DO, Gozho GN, McBride BW: Subacute ruminal acidosis in dairy cows: the physiological causes, incidence and consequences. Vet J 2008;176:21-31.

2 Kleen JL, Cannizzo C: Incidence, prevalence and impact of SARA in dairy herds. Anim. Feed Sci Technol 2012;172:4-8.

-3 Plaizier JC, Khafipour E, Li S, Gozho GN, Krause DO: Subacute ruminal acidosis (SARA), endotoxins and health consequences. Anim. Feed Sci Technol 2012;172:9-21.

4 Colman E, Khafipour E, Vlaeminck B, De Baets B, Plaizier JC, Fievez V: Grain-based versus alfalfa-based subacute ruminal acidosis induction experiments: similarities and differences between changes in milk fatty acids. J Dairy Sci 2013;96:4100-4111.

5 O'Grady L, Doherty ML, Mulligan FJ: Subacute ruminal acidosis (SARA) in grazing Irish dairy cows. Vet J 2008;176:44-49.

6 Tajik J, Nadalian MG, Raoofi A, Mohammadi GR, Bahonar AR: Prevalence of subacute ruminal acidosis in some dairy herds of Khorasan Razavi province, Northeast of Iran. Iran J Vet Res 2009;10:28-32.

7 Stefańska B, Nowak W, Komisarek J, Taciak M, Barszcz M, Skomiał J: Prevalence and consequence of subacute ruminal acidosis in Polish dairy herds. J Anim Physiol Anim Nutr (Berl) DOI:10.1111/jpn.12592.

8 Rodríguez-Lecompte JC, Kroeker AD, Ceballos-Márquez A, Li S, Plaizier JC, Gomez DE: Evaluation of the systemic innate immune response and metabolic alterations of nonlactating cows with diet-induced subacute ruminal acidosis. J Dairy Sci 2014;97:7777-7787.

9 Gao X, Oba M: Characteristics of dairy cows with a greater or lower risk of subacute ruminal acidosis: Volatile fatty acid absorption, rumen digestion, and expression of genes in rumen epithelial cells. J Dairy Sci 2016;99:8733-8745.

10 Pan XH, Yang L, Xue FG, Xin HR, Jiang LS, Xiong BH, Beckers Y: Relationship between thiamine and subacute ruminal acidosis induced by a high-grain diet in dairy cows. J Dairy Sci 2016;99:8790-8801.

$>11$ Aschenbach JR, Gäbel G: Effect and absorption of histamine in sheep rumen: significance of acidotic epithelial damage. J Anim Sci 2000;78:464-470.

12 Wang DS, Zhang RY, Zhu WY, Mao SY: Effects of subacute ruminal acidosis challenges on fermentation and biogenic amines in the rumen of dairy cows. Livest Sci 2013;155:262-272.

13 Jie Q, Kodithuwakku ND, Yuan X, He G, Chen M, Xu S, Wu Y: Anti-allergic and anti-inflammatory properties of a potent histamine $\mathrm{H} 1$ receptor antagonist, desloratadine citrate disodium injection, and its antiinflammatory mechanism on EA.hy926 endothelial cells. Eur J Pharmacol 2015;754:1-10. 


\section{Cellular Physiology Cell Physiol Biochem 2017;42:1109-1119 \begin{tabular}{l|l} 
DOI: 10.1159/000478765 & $\begin{array}{l}\text { O 2017 The Author(s). Published by S. Karger AG, Basel } \\
\text { www.karger.com/cpb }\end{array}$ \\
\hline
\end{tabular}}

14 Xu RX, Liu RY, Wu CM, Zhao YS, Li Y, Yao YQ Xu YH: DNA damage-induced NF- $\kappa$ B activation in human glioblastoma cells promotes miR-181b expression and cell proliferation. Cell Physiol Biochem 2015;35:913-925.

15 Rottenberg S, Schmuckli-Maurer J, Grimm S, Heussler VT, Dobbelaere DA: Characterization of the bovine IkappaB kinases (IKK)alpha and IKKbeta, the regulatory subunit NEMO and their substrate IkappaBalpha. Gene 2002;299:293-300.

16 Hu Z, Song B, Xu L, Zhong Y, Peng F, Ji X, Zhu F, Yang C, Zhou J, Su Y, Chen S, He Y, He S: Aqueous synthesized quantum dots interfere with the NF-кB pathway and confer anti-tumor, anti-viral and anti-inflammatory effects. Biomaterials 2016;108:187-196.

17 Li R, Wang J, Wang X, Zhou J, Wang M, Ma H, Xiao S: Increased $\beta$ TrCP are associated with imiquimodinduced psoriasis-like skin inflammation in mice via NF-кB signaling pathway. Gene 2016;592:164-171.

18 Zhang R, Zhu W, Mao S: High-concentrate feeding upregulates the expression of inflammation-related genes in the ruminal epithelium of dairy cattle. J Anim Sci Biotechno 2016;7:42.

19 Cuzzocrea S, Chatterjee PK, Mazzon E, Dugo L, Serraino I, Britti D, Mazzullo G, Caputi AP, Thiemermann C: Pyrrolidine dithiocarbamate attenuates the development of acute and chronic inflammation. Br J Pharmacol 2002;135:496-510.

20 Gozho GN, Plaizier JC, Krause DO, Kennedy AD, Wittenberg KM: Subacute ruminal acidosis induces ruminal lipopolysaccharide endotoxin release and triggers an inflammatory response. J Dairy Sci 2005;88:13991403.

21 AlZahal O, Rustomo B, Odongo NE, Duffield TF, McBride BW: Technical note: a system for continuous recording of ruminal pH in cattle. J Anim Sci 2007;85:213-217.

-22 Zhang M, Zhang S, Hui Q, Lei L, Du X, Gao W, Zhang R, Liu G, Li X, Li X: $\beta$-Hydroxybutyrate Facilitates Fatty Acids Synthesis Mediated by Sterol Regulatory Element-Binding Protein1 in Bovine Mammary Epithelial Cells. Cell Physiol Biochem 2015;37:2115-2124.

-23 Suber RL, Hentges JF, Gudat JC, Edds GT: Blood and ruminal fluid profiles in carbohydrate-foundered cattle. Am J Vet Res 1979;40:1005-1008.

24 Vo TS, Kim SK: Down-regulation of histamine-induced endothelial cell activation as potential antiatherosclerotic activity of peptides from Spirulina maxima official journal of the European Federation for Pharmaceutical Sciences. Eur J Pharm Sci 2013;50:198-207.

25 Dong H, Zhang W, Zeng X, Hu G, Zhang H, He S, Zhang S: Histamine induces upregulated expression of histamine receptors and increases release of inflammatory mediators from microglia. Mol Neurobiol 2014;49:1487-1500.

26 Wang WY, Chen Y, Su X, Tang D, Ben QW, Yao WY, Chen P, Yuan YZ: Resistin-Like Molecule- $\alpha$ Causes Lung Injury in Rats with Acute Pancreatitis by Activating the PI-3K/Akt-NF- $\kappa B$ Pathway and Promoting Inflammatory Cytokine Release. Curr Mol Med 2016;16:677-687.

27 Häcker H, Karin M: Regulation and function of IKK and IKK-related kinases. Sci STKE 2006;357:re13.

-28 Yu L, Li L, Medeiros LJ, Young KH: NF- $\mathrm{BB}$ signaling pathway and its potential as a target for therapy in lymphoid neoplasms. Blood Rev 2016;pii:S0268-960X:30046-30047.

-29 DiDonato JA, Mercurio F, Karin M: NF-kappaB and the link between inflammation and cancer. Immunol Rev 2012;246:379-400.

-30 Hayden MS, Ghosh S: Shared principles in NF-kappaB signaling. Cell 2008;132:344-362.

-31 Li X, Huang W, Gu J, Du X, Lei L, Yuan X, Sun G, Wang Z, Li X, Liu G: SREBP-1c overactivates ROS-mediated hepatic NF-кB inflammatory pathway in dairy cows with fatty liver. Cell Signal 2015;27:2099-2109.

-32 Aditya S, Humer E, Pourazad P, Khiaosa-Ard R, Huber J, Zebeli Q: Intramammary infusion of Escherichia coli lipopolysaccharide negatively affects feed intake, chewing, and clinical variables, but some effects are stronger in cows experiencing subacute rumen acidosis. J Dairy Sci 2016;100:1363-1377. 